Iga Kisa-Bogorodź

ORCID: 0000-0002-4297-7229

https://doi.org/10.26881/pwe.2019.47.13

Zespół Szkół Handlowych w Sopocie

igakisa@wp.pl

\title{
Dyskursywność klapsa w świetle rodzicielskich narracji
}

\section{Summary}

\section{The discursiveness of spanking in the context of parental narration}

In Poland there has been a ban on the use of corporal punishment of children since 2010. However, the results of the research presented in 2018 by The Ombudsman for Children of that time show that more than half of Polish parents use spanking in upbringing. In this paper I would like to find the reason why parents beat children, how they justify including corporal punishment or eliminating it from upbringing and how they perceive the child in mutual relations. A small part of the research presented by me is the result of the research process during which I conducted semi-structured interviews with parents. The material collected as the result of them was subjected to a phenomenographic analysis with the use of elements of the grounded theory and, as a result, three concepts of spanking which will be shown in the text appeared. The results of the research presented indicate that a spank is a discursive phenomenon which is perceived by some people as violence, harm and an unacceptable method in the educational process, and by others it is considered as a valuable, positive and needed element of mutual relations with the child. In the text I do not make an attempt to evaluate parental conceptions of spanking, but only to show the multiplicity of understanding it.

Keywords: child, discursiveness, spanking, violence, upbringing

Słowa kluczowe: dziecko, dyskursywność, klaps, przemoc, wychowanie

Stosunki rodzinne i panujący w rodzinie układ ról są ważnym czynnikiem kształtującym osobowość dziecka, jego poczucie własnej wartości, odczuwanie, kim jest, co mu wolno, a co nie należy do jego kompetencji. W domu rodzinnym zdobywamy pierwsze doświadczenia społeczne, emocjonalne i poznawcze, które wpływają na nasze późniejsze życie. Każda rodzina realizuje określony sposób swojego funkcjonowania, z którego wynika preferowany przez rodziców model wychowania. Bogusław Śliwerski, za szwedzkim pedagogiem Hansem Sanerem, opisuje trzy modele wychowania (Śliwerski 2007: 104-108). W pierwszym dziecko jest niepełną osobą, oznacza to, że nie jest na tyle mądre i dojrzałe, aby mogło decydować o sobie i o świecie. Model ten można odnieść do jednego z wyróżnionych przez Dorotę Klus-Stańską dyskursów dziecka uczącego się, nazywanego Dyskursem Systemu z Deficytami, w którym jest ono postrzegane jako niekompetentne, słabe, wymagające nieustannej kontroli (Klus-Stańska 2007: 94), jak również do układu kultury 
postfiguratywnej Margaret Mead, w której jedynymi autorytetami są rodzice i dziadkowie, będący dla dziecka źródłem wiedzy (Mead 2000: 23). W drugim modelu dziecko jest takim samym człowiekiem jak dorosły, a relacje opierają się na wzajemnej wymienności wiedzy i doświadczeń. Tej koncepcji odpowiada wyróżniony przez Klus-Stańską Dyskurs Demiurga/Konstruktora, w którym oddziaływanie w toku wychowania polega na prowadzeniu z dzieckiem negocjacji. Stosunki cechuje partnerstwo i zaufanie do możliwości dziecka, do jego mądrości (Klus-Stańska 2007: 100-101). Możemy go również odnieść do układu kultury kofiguratywnej Mead, w którym to rówieśnicy stanowią źródło wiedzy, co oznacza, że dzieci cechują takie same kompetencje jak dorosłych (Mead 2000: 46). Ostatni jest model autonomiczny, określany jako samowychowanie i autosocjalizacja. Dziecko jest autorytetem we własnych sprawach. Przedstawia go również krytyczno-emancypacyjny „Dyskurs Kontestatora” Klus-Stańskiej i układ kultury prefiguratywnej Mead, w którym dziecko jest głównym źródłem wiedzy (Mead 2000: 86).

Każdy z tych modeli wskazuje na odmienny sposób postępowania z dzieckiem. Inaczej bowiem kształtują się stosunki i układ sił w rodzinie, w której jest ono uznawane za jednostkę kompetentną i zdolną do samostanowienia, niż w rodzinie, w której konserwatywne wartości określają przywódczą rolę rodzica i posłuszeństwo dziecka, często osiągane przez system kar i nagród, a rodzicielski klaps stanowi w nich podstawę oddziaływań wychowawczych. Klaps jest kontrowersyjną kwestią szeroko dyskutowaną w przestrzeni prywatnej i publicznej. W Norwegii przemoc wobec dzieci, w tym również stosowanie klapsów, jest surowo i bezdyskusyjnie karana. W Polsce klaps jest zjawiskiem dyskursywnym, przez jednych uznawanym za przemoc i bicie, przez innych wykluczanym poza jej obszar i traktowanym jako pomoc w realizowaniu władzy rodzicielskiej. Na definiowanie klapsa wpływają: wartości i ideologia wychowania, która wyznacza pozycję dziecka, i klimat wychowawczy w rodzinie, ale również polityka danego państwa i jego regulacje prawne. W Polsce od 2010 r. Kodeks rodzinny i opiekuńczy zakazuje stosowania kar cielesnych, jednak przeprowadzone w 2018 r. przez ówczesnego Rzecznika Praw Dziecka, Marka Michalaka, badania pokazały, że prawie połowa polskich rodziców stosuje klapsy i uznaje je za dobry i pożądany element wychowania (zob. Jarosz 2018).

\section{Metodologia badań własnych}

Celem niniejszego artykułu jest próba przedstawienia niewielkiego wycinka badań własnych $^{1}$ ukazującego, w jaki sposób rodzice mówią o klapsach. Głównym problemem badawczym artykułu jest pytanie: Jakie są rodzicielskie koncepcje klapsów? Sformułowane problemy szczegółowe, które pomogą w zrekonstruowaniu rodzicielskich koncepcji klapsów, to pytania: Jak rodzicie definiują klapsy? Jak rodzice argumentują zasadność

\footnotetext{
1 Badania prowadziłam na potrzeby rozprawy doktorskiej zatytułowanej Prywatne dyskursy władzy rodzicielskiej. Zgromadzony materiał badawczy posłużył mi do zbudowania zaprezentowanych w artykule rodzicielskich koncepcji klapsa, które nie znajdują się jednak w przywołanej rozprawie doktorskiej.
} 
i słuszność ich stosowania bądź wykluczania z procesu wychowania? Jak rodzice określają pozycję dziecka we wzajemnych relacjach?

Przedstawiony w prezentowanym tekście fragment badań jest wynikiem analizy wywiadów przeprowadzonych z rodzicami. W moich badaniach wzięło udział 27 osób 19 kobiet i 8 mężczyzn w wieku 23-45 lat. Dobór osób do rozmów opierał się na metodzie kuli śnieżnej. Początkowo prowadziłam wywiady z rodzicami, których znałam, a moi rozmówcy wskazywali mi potencjalnie chętne osoby do wzięcia udziału w badaniu. W wyborze metody doboru próby kierowałam się zamiarem uzyskania jak najbardziej różnorodnej grupy badawczej. W związku z tym starałam się, aby wybrane osoby pochodziły z różnych środowisk (miasto, wieś), miały różne wykształcenie (zawodowe, średnie, wyższe), miały dzieci w różnym wieku, były osobami wychowującymi dzieci w pełnych, niepełnych czy zrekonstruowanych rodzinach, a także miały różne poglądy religijne. Oczywiście mam świadomość, że bazowanie na paradygmacie jakościowym oznacza skupienie się na niewielkiej liczbie osób, moim celem jednak było poznanie osobistych opinii rodziców, a nie generalizowanie wyników w odniesieniu do szerszej populacji.

Zaprezentowane $\mathrm{w}$ artykule koncepcje klapsa zostały zrekonstruowane na podstawie uzyskanego w wywiadach materiału, który został poddany postępowaniu badawczemu opartemu na założeniach fenomenografii i z wykorzystaniem elementów teorii ugruntowanej. Fenomenografia stanowi empiryczne studium ograniczonej liczby jakościowo różnych sposobów doświadczania, postrzegania, pojmowania, rozumienia, określania zjawisk i aspektów otaczającego świata. Celem analizy fenomenograficznej jest opisywanie sposobów nadawania znaczeń zjawisku stanowiącemu przedmiot zainteresowania badacza (Marton 1994: 44-45). Z założeń fenomenografii zaczerpnęłam takie obszary, jak: całościowe zapoznawanie się z tekstem, kondensacja, porządkowanie i grupowanie materiału pod względem podobieństw i różnic, artykulacja oraz kontrastowanie wyłonionych kategorii opisu.

Klasyczną metodologię teorii ugruntowanej (uznawaną przez niektórych badaczy za pozytywistyczną) opracowali Anselm L. Strauss i Barney G. Glaser (zob. Glaser, Strauss 2009). Alternatywna dla niej jest proponowana przez Kathy Charmaz wersja konstruktywistyczna, w której wiedza o świecie nie jest zdobywana pasywnie, ale przez aktywne zaangażowanie w badaną rzeczywistość. Znaczenia nie znajdują się „na zewnątrz”, ale są wytwarzane przez jednostki (Charmaz 2009: 18). W badaniach z teorii ugruntowanej zaczerpnęłam elementy kodowania wstępnego oraz możliwie maksymalne ograniczanie przedzałożeń, czyli mojej wiedzy, tak aby uzyskane wyniki były koncepcjami rodziców, a nie moimi.

Jak już wspomniałam, badania opierały się na kilku następujących po sobie etapach. Pierwszym z nich było gromadzenie danych. Zgodnie z założeniami fenomenografii odbywało się to przy zastosowaniu wywiadu semistrukturalizowanego, nazywanego również wywiadem półuporządkowanym (Kvale 2004: 132), półstandardowym (Konarzewski 2000: 117) czy częściowo ukierunkowanym (Kaufmann 2010: 33). Częściowa strukturyzacja oznaczała, że moje wywiady nie były całkowicie ustrukturyzowane, ale nie były też 
całkowicie „nieukierunkowane”. Przyjęcie takiego typu wywiadu umożliwiło mi otwartość w postępowaniu, co oznaczało, że w trakcie rozmowy miałam możliwość zmiany kolejności pytań czy zakresów tematycznych. Po przeprowadzeniu rozmów dokonałam ich transkrypcji. Następnie, zgodnie z założeniami fenomenografii, dwukrotnie zapoznałam się z całością tekstu. Kolejnym podjętym krokiem była kondensacja. Wyselekcjonowałam z tekstu fragmenty odnoszące się do interesującego mnie zjawiska, które poddałam kodowaniu wstępnemu, zaczerpniętemu z teorii ugruntowanej, nadając wypowiedziom etykiety. Po zakończeniu kodowania wstępnego, korzystając z założeń jakościowej analizy danych, przeszłam do kodowania tematycznego - bardziej skondensowanego i precyzyjnego określania, o czym mówili badani. Po zakończeniu tematyzowania, opierając się na zasadach analizy fenomenograficznej, porównywałam ze sobą skondensowane wypowiedzi, szukając podobieństw i różnic. Na podstawie analizy podobieństw i różnic zebrany materiał podzieliłam na kilka grup, które kolejno poddałam fenomenograficznej artykulacji, prowadzącej do identyfikacji odrębnych koncepcji zjawiska ujawniających się w uzyskanym materiale (Męczykowska 2003: 87). Następnie nazwałam i opisałam koncepcje wyłonione w toku grupowania i artykulacji. W wyniku analizy wyodrębniłam trzy koncepcje klapsów:
A. klaps jako przywołanie do posłuszeństwa;
B. klaps jako wyraz rodzicielskiej troski;
C. klaps jako nieobecny i szkodliwy element wychowania.

\section{A. Klaps jako przywołanie do posłuszeństwa}

W pierwszej wyłonionej koncepcji klaps jest definiowany jako skuteczna metoda modelowania i osiągania wymaganego zachowania dziecka, jego podporządkowania i sprowadzania na „właściwy” tor. W omawianej koncepcji klaps nie jest uważany za bicie, lecz jedynie za wzmocnienie, które pozwala rodzicowi na osiągnięcie posłuszeństwa i skorygowanie dziecięcych reakcji. Jest używany w sytuacji nieposłuszeństwa i oporu dziecka wobec decyzji rodzica. Klaps nie jest sytuowany w obszarze przemocy, określa się go jako coś, co nie boli i nie ma negatywnych konsekwencji. Rodzice oddzielają klaps od bicia, od fizycznego krzywdzenia, argumentując, że przecież nie katują dziecka, co jest dla nich niedopuszczalne. Klaps nie jest więc czymś, co szkodzi dziecku, jest metodą stosowaną od pokoleń, mieści się ona w następującej retoryce: przecież każdy dostawał klapsy i nie widać żadnych negatywnych konsekwencji ich stosowania w życiu dorosłym.

Dla mnie, jak dziecko jest nieposłuszne, to skuteczną, tak, to ja daję klapsa (...), to jej nie boli, to yyy..., nie wiem, yyy... mmm, nie, no nie uważam tego (...), że tutaj robię coś z jej ciałem, co, co, czego mogłabym, czego mogłaby nie życzyć sobie (...) (Karolina, 28 1.).

Ja uważam, że dziecku należy dać klapsa, jak jest nieposłuszne, jeden klaps w tyłek, wiadomo, że to nie zaboli jakoś tam bardziej, no, ale na pewno nie bicie, tak (...), ale wtedy 
zbystrzeje, tak, jakby dostał jakiegoś olśnienia, że robi coś złego i już robi to, co trzeba (Alicja, 30 1.).

Jak jest nieposłuszna, daję jej klapsa, taki jeden klaps, taki na otrzeźwienie czasami jest dobry, ale to musi być klaps, a nie, nie wiem, jakieś, jakieś już bicie powodujące już duży ból czy coś w tym guście, to musi być takie jak szturchnięcie, żeby, żeby do dziecka dotarło, ale mówię, nie, nie na tyle, żeby zostały jakieś tam siniaki (...) (Krzysztof, 36 1.).

Klaps jest najlepszą metodą, jak dziecko jest nieposłuszne, nie słucha się (...) nie uważam stosowania jakichś tam kar cielesnych, ale taki klaps, że tak powiem, delikatny. (...) Uważam, że klaps nie jest czymś złym, po prostu takim jakby impulsem, żeby się, żeby się dziecko ocknęło, (...) bo nie ma porównania do dania klapsa, a na przykład do człowieka, który katuje swoje dziecko (...) (Marek, 33 1.).

Wie Pani, no, jak ona nie chce, no, nie może, w ogóle nie słucha, nie reaguje na moje zdanie, to dam jej klapsa i no, po chwili przechodzi, dziecko się uspokaja naprawdę, jest posłuszne, ale klaps, nie bicie dziecka, nie, tylko klaps (Paweł, 28 1.).

W moim przypadku na syna działają klapsy, jak się nie słucha. Jak ja mu przyleję, to od razu jest poprawa, a taki klaps też nie zaszkodzi, wiadomo, nie jest tluczone (...) takiemu dziecku to się krzywda nie stanie (...) ja nie mówię tutaj o katowaniu czy przykładaniu pasem (...) klapsy były od zawsze, (...) wszyscy dostawali klapsy (...) dla mnie to jest nieszkodliwe (...) bo dziecko robi się spokojne, posłuszne (Grażyna, 30 1.).

Wypowiedzi rodziców pokazują, że definiują oni klapsy jako skuteczną metodę osiągania posłuszeństwa u dziecka i korygowania jego niewłaściwych zachowań. Argumentacja, jakiej używają do uzasadniania stosowania klapsów, opiera się na przekonaniu o braku ich negatywnych konsekwencji dla dziecka, klaps nie jest czymś, co powoduje ból, nie jest przemocą, od której rodzice zdecydowanie się odcinają. Jest metodą wychowawczą stosowaną od pokoleń, łagodnym środkiem, który pozwala osiągać zachowanie zgodne z oczekiwaniami dorosłego. W opisywanej koncepcji dziecko jest bierną jednostką, która zajmuje pozycję niesymetryczną względem dorosłego. Jego zadaniem jest stosowanie się do zaleceń rodzica i bezdyskusyjne podporządkowywanie jego decyzjom.

\section{B. Klaps jako wyraz rodzicielskiej troski}

W drugiej koncepcji klaps, oprócz funkcji egzekwującej posłuszeństwo, jest określany jako zjawisko niosące pozytywne doświadczenia dziecku, jako wyraz rodzicielskiej troski i działalność terapeutyczna. Takie rozumienie kar fizycznych można odnaleźć m.in. u Stanisława Sławińskiego, który twierdzi, że klaps, oprócz osiągania uległości, niesie za sobą „pozytywne dla dziecka przeżycie bliskości fizycznej z osobą wychowującą” (Sławiński 1991: 103). Podobnie swoje przekonania formułuje James Dobson, pisząc, że klapsy, które dziecko rozumie i docenia, są wyrazem miłości rodzica, a nie nienawiści 
(Dobson 1992: 29). Klaps w omawianej koncepcji jest uznawany za skuteczny i niezbędny element dyscyplinowania dziecka oraz bardzo potrzebny składnik wzajemnych relacji. Nie jest przemocą, ale metodą stosowaną przy poszanowaniu godności dziecka. Oprócz funkcji dyscyplinującej jest wyrazem zaangażowania rodzica, jego miłości i wsparcia. Chroni dziecko i zapobiega negatywnym dla niego konsekwencjom w przyszłości, dlatego nie jest przez nie odbierany negatywnie, ale jako wyraz rodzicielskiej troski o jego dobro i przyszłość. Rodzice uznają, że klaps daje poczucie bezpieczeństwa. Twierdzą, że dzieci w pewnych sytuacjach wręcz domagają się klapsa, który umożliwia powrót do równowagi emocjonalnej.

Ja uważam, że brak karcenia dzieci jest zły, tylko trzeba pamiętać, że klapsa daje się w odpowiedni sposób, żeby w normalny sposób, yyy... (...) przy poszanowaniu godności dziecka, klaps ma uczyć dziecko bycia posłusznym, (...) klaps ma nieść dla dziecka dobre rzeczy, (...) pokazuje dziecku, że musisz być mi posłuszny, że zależy mi na tobie (...) (Piotr, 33 1.).

(...) yyy... klaps też pokazuje właśnie to, że zależy mi na tym dziecku tak, że słuchaj, wolę teraz dać ci klapsa, niż masz potem wpaść później pod samochód na przykład, tak, yyy... czy że potem masz zostać na przykład złodziejem czy coś w tym stylu, tak, (...) tym bardziej że to są, to są klapsy, to nie jest jakieś tam, nie wiem, jak to piszą fizyczne znęcanie się czy coś takiego (Marta, 31 1.).

Też znajoma mi kiedyś opowiadała, że dziecko było niegrzeczne (...) i w momencie, kiedy dostała ta dziewczynka klapsa (...) to poprawila się, natychmiast, od razu przestała tam jęczeć, narzekać, cokolwiek to było to zachowanie, powiedziała, a teraz wiem, że mnie kochasz, tak, to było takie: teraz wiem, że ci na mnie zależy, (...) i rzeczywiście dziecko chyba czasami potrzebuje takiego wzmocnienia (...) (Ewelina, 33 1.).

Przy tym najstarszym dziecku to rzeczywiście czasem właśnie było tak, że, że to chodziło o klapsa, tak, trzeba było się zatrzymać gdzieś, dać klapsa, przytulić się i wtedy już było wszystko super i fajnie, i radocha, i wracanie do domu w podskokach, prawda (...) (Marta, 33 1.).

(...) czasami rzeczywiście jest tak, że dziecko wręcz prosi się o to lanie, w sensie takim, że potrzebuje tego, żeby się uspokoić nawet, tak, yyy... i to pomaga, i to pomaga, już zachowuje się normalnie (Marta, 31 1.).

Wiesz (...) ja miałam czasami naprawdę wrażenie, że, że to moje dziecko, mimo że dostało ode mnie klapsa, to w jakimś sensie, nie wiem, wdzięczne to jest za duże słowo, ale w jakimś sensie przynosilo mu to ulgę, bo on sobie nie mógł z taką sytuacją (...) i potem było wszystko dobrze, on tak nawet potrafil odetchnąć i powiedzieć „dobrze” (...) (Jolanta, 36 1.).

Prezentowane narracje pokazują, że rodzice, oprócz dyscyplinującej funkcji klapsa, widzą w nim źródło pozytywnych doświadczeń dziecka i funkcję profilaktyczną. 
Podobnie jak w pierwszej koncepcji, również tutaj wychowanek zajmuje pozycję podrzędną wobec rodzica. Jest jednostką, która nie ma możliwości bycia sobą, ponieważ jego zachowanie musi być zgodne z oczekiwaniami dorosłego. Uzasadnianie używania klapsów jest argumentowane dobrem dziecka, dbaniem i troską o jego przyszłość, rodzicielską miłością.

Dwie przedstawione koncepcje klapsa wpisują się w nurt wychowania konserwatywnego. W tej koncepcji dziecko jest uznawane za jednostkę niekompetentną, której zachowanie należy modelować zgodnie z oczekiwaniami obdarzonego autorytetem rodzica. We wzajemnych relacjach podstawą jest posłuszeństwo, przymus jest często stosowanym środkiem, a karność to główny czynnik wychowawczy (Zubelewicz 2002: 38). Wychowanie autorytarne - jak zauważa Alina Wróbel - zmierza do tego, by dziecko było osobowością przystosowaną do narzucanych przez wychowującego norm, celów, wartości (Wróbel 2006: 129).

\section{Klaps jako nieobecny i szkodliwy element wychowania}

W trzeciej koncepcji klapsa rodzic jest partnerem dziecka. Tutaj dziecko jako pełnowartościowy człowiek ma prawo do autentyczności w wyrażaniu swoich zachowań. Klaps jest uznawany za metodę, która niesie za sobą jedynie negatywne konsekwencje. Jest upokorzeniem dziecka, wyrazem frustracji dorosłego, przemocą, której nie powinien doświadczać żaden człowiek. Jest naruszeniem nietykalności cielesnej, przykrością, która na długo lub na zawsze pozostaje w pamięci dziecka. Klaps nie jest metodą, która eliminuje negatywne zachowania, lecz jedynie krzywdą dziecka, która burzy jego poczucie własnej wartości, godności, uczy rozwiązywania konfliktów przemocą.

(...) Dawanie klapsów nie powinno mieć miejsca. (...) Dziecko jest czlowiekiem takim samym jak dorosły. Skoro nie biję nikogo, jak mogłabym uderzyć dziecko. (...) Wiesz, jak bijesz dziecko, to ono myśli, że bicie rozwiązuje sytuację, a to nie jest moim zdaniem rozwiązanie, tylko upokorzenie siebie i dziecka (Emilia, 30 1.).

Ja nie jestem za biciem dzieci, klapsy nie wchodzą w grę, dziecko jest moim partnerem, dorosłych nie biję, więc jak mogę bić dziecko, i uważam, że to jest tylko i wyłącznie uzewnętrznienie emocji rodziców. (...) Sama, będąc bita przez moich rodziców, że klapsy dostawałam, (...) nigdy bym nie chciała, żeby Lila dostawała, to jest takie upokorzenie, (...) ja myślę, że ja nie pamiętam tego lania, tylko to, jak się czułam, taka w ogóle przykrość (...) (Jana, 23 1.).

Ja jestem przeciwna biciu dzieci, moje dzieci są dla mnie tak samo ważnymi osobami jak mój mąż, którego nie biję, prawda. (...) jakby przemoc jest przemocą, jakby niezależnie od tego, do kogo jest skierowana, (...) bo dziecko jest zawsze na slabszej pozycji, a dziecko to taki sam czlowiek jak my, ja powiem pani szczerze, doświadczanie przemocy to jest taki wstyd i poniżenie i wiele dzieci się nie przyznaje do tego, wstydzi się (Monika, 41 1.). 
Ja nie uznaję bicia, klapsów, bo bicie to jest tak, że już innych argumentów nie mamy (...) to jest wykorzystywanie tego, że jesteśmy silniejsi, więksi (...) a to jest tak naprawdę słabość, bo (...) dlaczego nie uderzysz dorosłego, bo jest duży, tak, bo sobie na to nie pozwoli, dlaczego z dorosłym rozmawiasz, a nie rozmawiasz z dzieckiem, tylko je bijesz, bo masz przewagę właśnie, (...) to jest słabość (...) moje dziecko jest takim samym czlowiekiem jak dorosły, ja sobie nie wyobrażam jej bicia, bo nikogo nie biję (Dorota, 36 1.).

W trzeciej koncepcji klaps jest definiowany jedynie w pejoratywnym kontekście. Jest przemocą, wykorzystywaniem przewagi dorosłego, brakiem umiejętności radzenia sobie z zachowaniem dziecka. Niestosowanie klapsów rodzice argumentują partnerską relacją z dzieckiem, które jest dla nich takim samym człowiekiem jak dorosły, w związku z czym zasługuje na traktowanie $\mathrm{z}$ równym szacunkiem. Takie podejście do procesu wychowania wpisuje się w nurt wychowania liberalnego, w którym relacje są symetryczne. Dziecko jest aktywnym podmiotem rozwijanym od wewnątrz, a nie formowanym zewnętrznie. W procesie wychowania ma możliwość wyrażania siebie. Wzajemne relacje charakteryzuje demokratyczny, a nie hierarchiczny układ stosunków. Jego podstawą jest wolność, która oznacza konieczność traktowania wszystkich, bez względu na wiek, z równą troską i szacunkiem (Kelly 2007: 93).

Zrekonstruowane koncepcje klapsa pokazują, jak odmiennie jest on definiowany przez rodziców, jak różnorodnej argumentacji używają do uzasadnienia jego stosowania bądź wykluczenia w procesie wychowania. Można zauważyć, w jak sprzeczny sposób kształtują się wzajemne relacje i wynikające z nich pozycje dziecka i rodzica. Syntetyczne ujęcie prezentowanych koncepcji przedstawiono w tabeli 1.

Tabela 1. Koncepcje klapsa - ujęcie syntetyczne

\begin{tabular}{|l|l|l|l|l|}
\hline \multicolumn{1}{|c|}{ Koncepcja } & \multicolumn{1}{|c|}{ Definiowanie } & \multicolumn{1}{c|}{ Argumentacja } & \multicolumn{1}{c|}{ Dziecko } & \multicolumn{1}{c|}{ Rodzic } \\
\hline $\begin{array}{l}\text { klaps jako } \\
\text { przywołanie do } \\
\text { posłuszeństwa }\end{array}$ & $\begin{array}{l}\text { metoda osiągania } \\
\text { posłuszeństwa, } \\
\text { łagodny środek } \\
\text { wychowawczy }\end{array}$ & $\begin{array}{l}\text { brak } \\
\text { negatywnych } \\
\text { konsekwencji, } \\
\text { stosowany od } \\
\text { pokoleń }\end{array}$ & $\begin{array}{l}\text { posłuszne, } \\
\text { podporządkowane, } \\
\text { bierne }\end{array}$ & $\begin{array}{l}\text { przywódca, } \\
\text { autorytet }\end{array}$ \\
\hline $\begin{array}{l}\text { klaps jako wyraz } \\
\text { rodzicielskiej } \\
\text { troski }\end{array}$ & $\begin{array}{l}\text { środek } \\
\text { dyscyplinujący, } \\
\text { wyraz } \\
\text { rodzicielskiej } \\
\text { miłości i troski }\end{array}$ & $\begin{array}{l}\text { dbanie o dobro } \\
\text { dziecka, } \\
\text { troska o jego } \\
\text { przyszłość }\end{array}$ & uległe, posłuszne & $\begin{array}{l}\text { przywódca } \\
\text { dbający } \\
\text { o przyszłość } \\
\text { dziecka }\end{array}$ \\
\hline $\begin{array}{l}\text { klaps jako } \\
\text { nieobecny } \\
\text { i szkodliwy } \\
\text { element } \\
\text { wychowania }\end{array}$ & $\begin{array}{l}\text { przemoc, } \\
\text { wyraz frustracji, } \\
\text { słabość rodzica }\end{array}$ & $\begin{array}{l}\text { krzywdzenie } \\
\text { dziecka }\end{array}$ & $\begin{array}{l}\text { partner, autorytet, } \\
\text { autentyczne }\end{array}$ & partner \\
\hline
\end{tabular}

Źródło: opracowanie własne. 


\section{Podsumowanie}

Podsumowując niniejsze rozważania, można wskazać, że klapsy, mimo że są niedopuszczalne $\mathrm{i}$ od prawie dziesięciu lat zakazane w naszym porządku prawnym, nadal pozostają elementem dyscyplinowania dzieci w polskich rodzinach. Kategoria klapsów, o czym świadczą wyniki badań, jest przedmiotem dyskursu - różnorodnie rozumianym i definiowanym. Jedni rodzice uznają klapsy za skuteczny i właściwy środek oddziaływania i kształtowania zachowania dziecka, za pozytywne wzmocnienie, które pomaga osiągać posłuszeństwo. Nie sytuują ich w obszarze przemocy wobec dziecka, uznają, że klaps nie boli. Część z dorosłych wskazuje na pozytywne doświadczenia dziecka, wynikające ze stosowania kar cielesnych, takie jak rodzicielska miłość i troska, a także zaangażowanie w życie dziecka. Inni rodzice definiują klapsy jako przemoc i nie wyobrażają sobie ich używania wobec dziecka, które jest dla nich pełnowartościowym człowiekiem. Klapsy traktują jedynie w kategoriach negatywnych. Takie zróżnicowane rozumienie kar fizycznych pokazuje, jak odmiennie podchodzimy do kwestii bicia dzieci. Dla jednych klapsy są niewyobrażalną krzywdą wyrządzaną dziecku, dla innych - wyrazem troski i miłości.

Jak zauważa Klus-Stańska, na przestrzeni ostatnich lat „Polska znajduje się w polu krzyżujących się ideologii, często skrajnie odmiennych. (...) Konserwatywnym, uniwersalizującym wizjom dziecka (...) towarzyszą w dyskursach publicznych liberalne postulaty wolnościowe i postmodernistyczna fragmentaryzacja świata; tęsknota za tradycyjną dyscypliną (...) współwystępuje z oczekiwaniem edukacji wyzwalającej niepokorność intelektualną i samodzielność etyczną; interwencyjno-perswazyjne klimaty polskiej kultury pedagogicznej zderzają się z myśleniem o dziecięcej mądrości” (Klus-Stańska 2009: 38). Ostatnio możemy obserwować spowolnienie tych zmian i zwrot ku tradycyjnym wartościom, czemu podwaliny daje obecna polityka państwa, w której dominują konserwatywne poglądy na wychowanie oraz role dziecka i rodziny. $Z$ jednej strony udało się osiągnąc zaostrzenie prawa w zakresie stosowania przemocy wobec dzieci, z drugiej zaś niepokojące jest to, że osoby mające stać po stronie dzieci i dbać o ich dobro nie traktują klapsa jako przemocy/bicia, co więcej, z estymą wspominają klapsy otrzymywane w dzieciństwie.

\section{Literatura}

Charmaz K. (2009), Teoria ugruntowana. Praktyczny przewodnik po analizie jakościowej. Warszawa, Wydawnictwo Naukowe PWN.

Dobson J. (1992), Uparte dziecko. Od narodzin do wieku młodzieńczego. Warszawa, Alfa-Omega. Glaser B.G., Strauss A.L. (2009), Odkrywanie teorii ugruntowanej. Strategie badania jakościowego. Kraków, Zakład Wydawniczy NOMOS.

Jarosz E. (2018), Postawy wobec przemocy w wychowaniu - czy dobra zmiana? Raport Rzecznika Praw Dziecka 2018, https://brpd.gov.pl/sites/default/files/raport_2018.pdf, 23.10.2019.

Kaufmann J.-C. (2010), Wywiad rozumiejacy. Warszawa, Oficyna Naukowa.

Kelly P. (2007), Liberalizm. Warszawa, Wydawnictwo Sic! 
Klus-Stańska D. (2007), Między wiedzą a władzą. Dziecięce uczenie się w dyskursach pedagogicznych. „Problemy Wczesnej Edukacji”, 1/2.

Klus-Stańska D. (2009), Dyskursy pedagogiki wczesnoszkolnej. W: D. Klus-Stańska, M. Szczepska-Pustkowska (red.), Pedagogika wczesnoszkolna-dyskursy, problemy, rozwiazania. Warszawa, Wydawnictwa Akademickie i Profesjonalne.

Konarzewski K. (2000), Jak uprawiać badania oświatowe. Metodologia praktyczna. Warszawa, WSiP.

Kvale S. (2004), Interview. Wprowadzenie do jakościowego wywiadu badawczego. Białystok, Trans Humana.

Marton F. (1994), Phenomenography. W: T. Husén, T. Neville (eds.), The International Encyclopedia of Education. Vol. 8. Postlethwaite, Pergamon.

Mead M. (2000), Kultura i tożsamość. Studium dystansu międzypokoleniowego. Warszawa, Wydawnictwo Naukowe PWN.

Męczykowska A. (2003), Fenomenografia jako podejście badawcze w obszarze studiów edukacyjnych. „Kwartalnik Pedagogiczny”, 3(189).

Sławiński S. (1991), Spór o wychowanie w postuszeństwie. Warszawa, Agencja Wydawnicza TFD.

Śliwerski B. (2007), Pedagogika dziecka. Studium pajdocentryzmu. Gdańsk, Gdańskie Wydawnictwo Psychologiczne.

Wróbel A. (2006), Wychowanie a manipulacja. Kraków, Oficyna Wydawnicza „Impuls”.

Zubelewicz J. (2002), Filozofia wychowania aksjocentryzm i pajdocentryzm. Warszawa, Wydawnictwo Akademickie „Żak”. 